\title{
“TODOS SERÃO TEODIDATAS” (JO 6,45): DOCILIDADE AO ESPÍRITO, AUTENTICIDADE DA CONSCIÊNCIA E OBEDIÊNCIA À IGREJA
}

"Everyone will be teodidatas" (Jo 6:45): Docility to the Spirit, authenticity of conscience and obedience to the Church

Frei Carlos Josaphat*

RESUMO: O artigo apresenta a ética de liberdade proposta pelo Concílio Vaticano II para a Igreja e o mundo. Parte da afirmação: "Todos serão teodidatas", ou seja, no íntimo da consciência todos os seres humanos abertos ao transcendente estarão unidos direta e imediatamente a Deus. Considera vários paradigmas éticos formulados pelo Concílio. No paradigma pneumatológico ressalta a centralidade da ação do Espírito Santo. A docilidade à Palavra e ao Espírito Santo constitui atitude fundamental para se viver em autenticidade da consciência e obediência à Igreja. No paradigma eclesiológico reflete sobre a Igreja Povo de Deus como comunhão no Espírito e do Espírito; como sacramento do Amor, dedica-se à amplidão e profundidade do Amor, o que é decisivo para o aggiornamento proposto por João XXIII. No paradigma antropológico, mostra a conquista da compreensão de unidade entre dignidade singular da pessoa e a imagem divina da tradição bíblica; sobressai-se o valor da liberdade e o dom da fé, que fundamenta a ética dos valores; esta integra e leva à perfeição a aspiração à liberdade e às liberdades.

Palavras-Chave: Espírito Santo, Consciência, Ética, Dignidade, Liberdade.

Abstract. The article presents the ethic of freedom proposed by the Second Vatican Council for the Church and the world. Part of the statement: "all will be teodidatas", in other words, in the depths of consciousness every human being open to the transcendent will be united directly and immediately to God. Consider various ethical paradigms formulated by the Council. In the pneumatological paradigm the emphasis is on the centrality of the Holy Spirit. The docility to the Word and to the Holy Spirit is a fundamental attitude to live in authenticity of conscience and

* Professor Emérito da Universidade de Fribourg, Suíça. Artigo submetido a avaliação em 20.08.2012 e aprovado para publicação em 23.09.2012. 
obedience to the Church. In the Ecclesiological paradigm the reflection on the Church, people of God, as communion in the Spirit and of the Spirit; as sacrament of Love, is dedicated to the breadth and depth of love, what is decisive for the "aggiornamento" proposed by John XXIII. In the anthropological paradigm, the conquest is revealed of the understanding of unity between singular dignity of the person and the divine image of biblical tradition; excels the value of freedom and the gift of faith, which is the basis of the ethical values; this integrates and brings to perfection the aspiration to freedom and freedoms.

KeYwords: Holy Spirit, Conscience, Ethics, Dignity, Freedom.

\begin{abstract}
A docilidade ao Espírito, a autenticidade da consciência e a obediência à Igreja, essa trilogia de atitudes que qualificam o sujeito ético surge qual desafio radical e constante no decorrer da história do Ocidente moderno. No centro da ética cristã, a docilidade ao Espírito destaca a transcendência a que tende a consciência do sujeito racional e livre. A consciência de maneira autêntica se guia pela obediência à Igreja, na medida em que esta se afirma e é reconhecida em sua missão de fiel mediadora do Espírito de verdade, de amor e de santidade. Pela docilidade a esse Espírito, pela afinidade à sua presença transformadora, o Evangelho assegura, que na religião "em espírito e verdade" (Jo 4,25) "todos serão teodidatas" (Jo 6,45) ${ }^{1}$. O que significa literalmente, no santuário do coração, no íntimo da consciência, todos estarão unidos direta e imediatamente a Deus.
\end{abstract}

Uma convergência significativa marca os últimos decênios. Esses valores de base são expostos e elucidados pelo Concílio Vaticano II. Ele os articula em seu projeto de renovação evangélica da Igreja, no seu diálogo com o mundo, visando parceria na busca de uma ética universal para a humanidade globalizada.

De forma mais ampla, merece ainda atenção a confluência de aspirações e de valores éticos em muitas religiões, que se empenham em homologar um modelo autêntico e viável de ética mundial. Elas sintonizam assim com bom número de tendências, de grupos, de Ongs e movimentos que se preocupam com a urgência de uma equivalente promoção dos valores e direitos univer-

\footnotetext{
${ }^{1}$ Parece-nos importante manter na tradução do texto grego toda a força do "teodidatas", termo escolhido pelo Evangelista como síntese da Nova Aliança prometida "pelos Profetas". Esse tema da Nova Aliança, entendida e acolhida como dom da Verdade transformadora do ser íntimo do homem, está na base de nossa reflexão, aqui e em outros escritos, sobre a conjunção ética da docilidade ao Espírito, da autenticidade da consciência e da obediência à Igreja, na medida em que ela é e se afirma mediadora de Cristo e do seu Espírito no decorrer da história. Esse tema é tratado amplamente na I Parte, em três capítulos, de meu livro Ética mundial, Esperança da humanidade globalizada: "Ética humana e religiosa em busca da universalidade na Bíblia e na história" (Op. cit. Petrópolis: Vozes, 2010, p. 43-116).
} 
sais na própria marcha cultural, política e econômica da humanidade. Sua inquietude os leva a enfrentar a questão crucial: como dar uma qualidade plenamente humana à globalização, envolvida e manipulada pelos interesses e pelas ambições do utilitarismo individual e corporativo.

Essa onda de preocupações que põem em jogo os valores e as qualidades morais das pessoas, bem como o curso e o sentido da história, evoca o lado nobre, mas discreto e escondido, da civilização atual, em sua dimensão secular e religiosa. Como consequência natural, ganham relevo e ocupam a primeira cena os múltiplos obstáculos à viabilidade generalizada desses ideais, que se veem barrados pela solidez dos sistemas dominantes, por vezes estigmatizados como outros tantos monstros frios alienados e alienantes.

Será, portanto, oportuno estender a reflexão até a marcha, o progresso e os recuos, os conflitos e as ambiguidades que caracterizam a história da ética, considerada na sua orientação e no confronto de seus projetos e protagonistas na cristandade e na modernidade ocidental. Esse vasto contexto cultural e ético, anterior, simultâneo e posterior ao Concílio confirma a apreciação autorizada de Paulo VI ao encerrá-lo: "o Vaticano II é o maior de todos os Concílios". Assim se elucidam o sentido e a razão do paradigma teológico conciliar e o feixe de paradigmas éticos que ele inspira. Também cresce a viabilidade do projeto renovador e mesmo inovador que vem a ser o conjunto de seus dezesseis Documentos. O estudo desse ponto de chegada lança uma intensa luz retroativa sobre as buscas, as aspirações e inquietudes, bem como sobre as crises e os conflitos da antiga cristandade e do mundo moderno.

\section{Valores humanos e evangélicos em busca de viabilidade universal}

É verdade que já a evocação inicial da trilogia ética e cultural esboça ou pelo menos prenuncia a consciência da necessidade urgente de uma convivência pacífica de toda a humanidade, em contraste com uma herança de controvérsias senão de crises marcando um longo passado, que não deixa de parasitar amplos setores da religião e da sociedade de hoje.

O projeto e o dom evangélicos da docilidade ao Espírito testemunham o ideal de uma afinidade e de uma união de orientação teologal e mística como vocação transcendente da humanidade. A autenticidade da consciência, que traduz normalmente o consenso, a comunhão livre e intelectual das pessoas e das comunidades, só será possível com a realização plena e universal de uma ética partilhada pela humanidade, para além da predominância dos interesses da curiosidade e do proveito, que animam e ativam todas as redes da comunicação tecnológica.

O apelo à obediência à Igreja, entendida como a Igreja hierárquica, relembra ou pelo menos implica algo também de um contraste. Sob o nome de 
Igreja, distingue-se, com o risco de se opor, a autoridade eclesiástica, e como sujeito da obediência se designa o povo de Deus, enquanto rebanho confiado à guarda e à vigilância dos Pastores.

A reflexão teológica e mesmo cultural mais clarividente se desdobra hoje entre dois polos, impondo-se um e outro como dados que não se podem esquivar, pois surgem da verdade de base, em que se entrelaçam o mistério da Igreja e a realidade humana. Toda sociedade e, em grau de excelência máxima, a Igreja comportam um objetivo ideal. Este se concretiza no consenso e na convergência de todos os seus membros, em vínculos sociais ou comunitários, de autenticidade humana ou evangélica. Tais valores hão de penetrar e harmonizar o todo social em uma busca efetiva do bem comum que integre e supere os interesses e conflitos particulares.

Essa visão compreensiva se completa por uma noção e uma configuração concreta da Igreja como Comunhão de graça e de amor, unindo seus fiéis como chamados à santidade sob uma autoridade colegial, que não se caracteriza pelo mando mas pela atitude de serviço. Tal é a eclesiologia elaborada pelo Vaticano II, especialmente quando chegou ao auge de sua consciência conciliar expresso na Constituição Lumen gentium (de 21 de novembro de 1964). A vantagem dessa imagem ideal erguida pelo Concílio é que ela oferece um critério de referência e apreciação da qualidade evangélica da Igreja, ontem e hoje. Ela se mostrará autêntica na medida em que tenha a coragem e a humildade de se olhar no espelho do Evangelho e de se aceitar na verdade como santa e pecadora, como sempre reformada e a reformar, como vivendo e pregando sempre a conversão ao Amor e à Santidade de Deus.

Para a Igreja, sociedade humana e comunhão divina, o teste infalível e inexorável é o tipo e a qualidade de poder e de obediência que efetivamente nela prevalecem. Imagem da missão confiada à Igreja, o cajado na mão dos Pastores não é símbolo nem instrumento de imposição ou de amedrontamento. É um dom vindo do Amor e em clima de confissão e compromisso de Amor. É a mensagem do Evangelho (condensada em Jo 21, 15-17).

\section{Suprema distorção ética e social, a sacralização do poder absoluto}

Convém partir do que é mais visível: o paradoxo do poder, em sua dupla dimensão de uma autoridade efetiva e do bem comum, de que ela está ou não a serviço. A vigilância contra todo desvio, sempre insinuante e ameaçador, a predominância efetiva do serviço na compreensão mesma do poder, são atitudes primordiais que se enraízam no Evangelho. A insistência do Mestre divino é uma das primeiras expressões da originalidade do Reino de justiça e santidade que ele prega.

Sob forma de reivindicação, nem sempre desinteressada, essa exigência emerge como aspiração crescente da humanidade através da história. Esse 
ideal se incandesce e explode na aurora da modernidade, na tendência cada vez mais firme e forte de abrir ou rasgar caminhos à emancipação dos indivíduos, dos grupos, das classes ou camadas sociais.

De início, na primeira vaga de emancipação renascentista, não há uma recusa de Deus nem de Cristo ou do Evangelho. O que se quer relegar é a autoridade da Igreja, que é ressentida, denunciada e combatida como modelo de poder absoluto religioso, contrário à liberdade, à autonomia e à dignidade humanas. É preciso abater o altar juntamente com o trono, uma vez que são aliados e revestem, um e outro, o mesmo tipo de poder absoluto, de imposição forçada da ordem e da ortodoxia.

Pelos líderes e mestres espirituais foi sentida como necessária a libertação da Igreja das redes de ambições políticas e eclesiásticas. Mas o que se viu foi o escândalo dos imensos conflitos e lutas dos dois gládios, que dilaceravam a cristandade, sobretudo no século XIV. Ainda bem, a grande história dos desvios foi contrabalançada pelo zelo de Catarina de Sena, santa Doutora apaixonada pela Igreja que ela venerava e ensinava a venerar como "Corpo Místico" de Cristo. Então, o humanismo emancipacionista, a rebeldia libertária dos fins do século XV e inícios do século XVI, inaugurava o anticlericalismo sistemático e cada vez mais agressivo, na medida mesma em que combatia os dois poderes, o eclesiástico e o civil, sendo por ambos detestado.

Em literatura, a expressão mais atraente e insinuante do combate ao poder absoluto, religioso e profano, são as Utopias. Seus autores não visam apenas desenhar imagens inocentes de ilhas, de cidades ou regiões de perfeição ideal. Na imaginação e na pena de Thomas More, a Utopia não é um vago exercício da fantasia. O que se mostra e descreve, com todo esmero, sobretudo na sua II Parte, é uma realização alternativa, que livre a humanidade de países ou regiões, que se tornaram inaceitáveis. Nestes, prosperavam vícios e corrupções, que era preciso combater e eliminar. O recurso direto dos teólogos à Utopia para criticar a Igreja é uma proposta de alternativas reformistas, tidas como urgentes. Em geral se aponta para o ideal de uma Igreja de Deus e dos homens, em contraste com a realidade histórica de uma sociedade religiosa, vista e estigmatizada como entulhada de dogmas, de tradições, de formas de poder tirânico e dominador.

A Igreja era desdenhada como símbolo das trevas para a razão e de opacidade impedindo o acesso à Revelação da Verdade divina. Tal é sentido bem imaginado e bem divulgado pelo teólogo dominicano Tommaso Campanella em a Cidade do Sol, publicado em 1623. A futura e ideal Cidade do Sol resplandecerá como a perfeita e clara revelação de Deus, iluminando plenamente a inteligência de todos e de cada um. Não será como a Cidade da Lua, cidade da penumbra, dos dogmas obscuros para o povo, de mandamentos e instituições que estorvam as atividades da razão e da liberdade, recorrendo à violência política e policial para subjugar a população sem conhecimento e sem defesa. É a imagem 
sobrecarregada e distorcida da Igreja, da religião da cristandade, que desperta o ressentimento dos pobres e do conjunto do povo, oprimindo-os e os provocando qual Igreja aliada do poder e dos poderosos. Ela se impõe sob forma de poder absoluto em nome do poder divino.

\section{Apelo ao Espírito Santo contra o poder religioso na cristandade}

Uma reação mais radical tem sua origem na oposição ao poder e aos poderosos, cuja prepotência marcava o rosto da Igreja, desestimada senão detestada por andar de mãos dadas com a tirania estabelecida. Surgem movimentos e mestres espirituais, que se afirmam e consolidam pelo apelo ao Espírito Santo, declarado ausente da Igreja institucional e proclamado presente nos pobres, nos relegados pela sociedade.

Pode-se tomar como referência a figura e a obra do Abade Joaquim de Fiore, significativa em si e pela atenção que tem merecido em diferentes correntes culturais. Já a partir da plena Idade Média, o Espírito Santo surge quase como um pomo de discórdia no Ocidente cristão².

De um lado, como já fizera com Cristo, a cristandade passa a atribuir ao Espírito uma função de "assistência" ao poder e ao magistério da Igreja, qual auxílio oportuno e constante, invocado para garantir, prevenir, auxiliar e homologar o ensino eclesiástico oficial, dando-o como indefectível e assegurando uma autoridade incontestável às suas intervenções corretivas e mesmo punitivas.

Por outro lado, uma atenção voltada prioritária senão exclusivamente para o caráter redutivo e distorcido dessa primeira tendência, vai no sentido totalmente oposto. O Espírito Santo é acolhido e enaltecido como Fonte de vida, de amor, de santidade, mas habitando o coração dos fiéis. Por suas graças e seus carismas, o Espírito é reconhecido qual dom e força da Comunidade da Nova Aliança, robustecendo-a para triunfar da prepotência dominadora, do poder absoluto e concentrado nas autoridades hierárquicas da Igreja.

“Cristo estaria dividido?", perguntava Paulo aos Coríntios em tom irretorquível diante do que era absolutamente inaceitável (cf. 1 Cor, 1, 13). A questão se agrava quando o próprio Espírito de Amor e Comunhão se torna ocasião de desentendimento em toda a Igreja e durante séculos.

Hoje, ao considerar o conjunto dos Documentos do Vaticano II e seu processo histórico, tranquilo, mas, firme em enfrentar e superar conflitos, bem

\footnotetext{
${ }^{2}$ Joaquim de Fiore (ou de Flora) - 1135-1202 - propõe a visão da história da salvação em três Idades, do Pai, do Filho e do Espírito Santo, "profetizando" que após a cristandade teríamos o advento da Idade do Espírito Santo, para a paz do mundo e a Felicidade de todos. Ver meu livro Tomás de Aquino e a Nova Era do Espírito. São Paulo: Loyola,1998, especialmente p.189-236. Boa síntese do tema em FRANCO, José Eduardo. Joaquim de Flora e a Idade do Espírito Santo. Communio. Lisboa, v. XIV, n. 6, p. 544-552, 1997.
} 
se poderia dizer que ele se oferece como a resposta plena e adequada a essa interrogação angustiosa, que se perpetua no decorrer das gerações.

\section{A consciência, versão ética da lei inscrita no coração}

Convém completar a evocação dessa distorção plurissecular do poder, pela consideração, ainda que sumária, das vicissitudes históricas da consciência na Igreja e na cultura. Assim se prepara a compreensão da realidade e dos caminhos da autenticidade da consciência. Sem que seja mencionada, ela se deixa reconhecer logo nos primórdios luminosos da espiritualidade cristã, sintetizados no Sermão da Montanha. O Evangelho (especialmente Mt 5-7) aponta para a origem e a motivação da ascensão ética, proposta em termos mais simples: basta, mas é imprescindível, que o olhar do coração se volte amoroso para o coração do Pai que está nos céus. A transcendência, realçada em um vaivém de intimidades entre o céu e a terra, se revela e mesmo se dá na imanência de uma graça que transforma, eleva e valoriza o sujeito ético.

É a correlação bem compreendida do Infinito e do finito, da Verdade Divina e da verdade humana, que se iluminam mutuamente, excluindo até a sombra de rivalidade ou concorrência entre Criador e criatura. $\mathrm{O}$ valor singular da ética evangélica surge e se afirma nesta sua qualidade eminente de encontro íntimo da criatura com o Criador, que lhe dá uma criatividade, uma capacidade de autorrealização, elevando o que seu ser criado tem de melhor e de mais próprio. No limiar de sua Ética Fundamental, no Prólogo e nas cinco primeiras Questões da Segunda Parte (I-II) da Suma de Teologia, Tomás de Aquino se refere ao sujeito ético nestes termos audaciosos Homo capax Dei. O ser humano na primeira Parte da Suma é mostrado e elucidado como ser de Deus, infinitamente distinto, mas totalmente imantado para Deus, na afinidade de uma participação ontológica que vem a ser a Ação criativa de Deus. Na entrada da II Parte, o mesmo ser humano é reconhecido e enaltecido qual sujeito ético e responsável de sua autorrealização. Ele é dito imagem de seu Criador, porque este lhe deu a missão e a capacidade de se "criar" espiritualmente, de se dar uma existência ética, que é assumida e elevada em uma transcendência divina ${ }^{3}$.

Ainda aqui nossa reflexão se apoia em dois polos da experiência cristã se desdobrando na história. No início de um amplo e constante processo de inculturação, um dos primeiros escritos apostólicos testemunha o encontro da mensagem tipicamente bíblica do "coração", - no qual Deus estabeleceu a Aliança perfeita e definitiva, - com a consciência, a sineidesis, dado mais íntimo e típico da ética helenística e romana, tendo sua doutrina esboçada pelos mestres do estoicismo. Na Primeira Carta aos Coríntios,

${ }^{3}$ É um aspecto do "Paradigma teológico" de Tomás de Aquino, abordado por mim em recente publicação (com esse título), na Editora Paulus, São Paulo, 2012. 
que no prolongamento das Cartas aos Romanos e aos Gálatas, merece o titulo da primeira exposição elaborada da ética cristã, o questionamento ético dos destinatários levará à confluência, à sinergia, que Paulo estabelece entre a syneidesis e a ágape. Reagindo aos elementos de uma ética parcial e distorcida de uns tantos líderes da comunidade, o Apóstolo lança os fundamentos de uma ética integral, inspirada e orientada pela verdade e pelo amor, nos termos do Evangelho (cf. 1 Cor 8-9).

Paulo começa propondo uma solução concreta dentro da problemática dos interlocutores. Mostra a necessidade de articular conhecimento e amor, de bem formar a consciência e de ter em conta e respeitar a "consciência dos fracos", evitando "escandalizá-los". O que seria incorrer no risco de levar à perdição "aqueles por quem Cristo deu sua vida". O que aconteceria se os expusessem a agir contra a consciência, mesmo mal informada e errônea. Tal é a bela lição de ética evangélica elaborada no contexto e na linguagem de uma comunidade helenística.

Mas o que mais interessa é a síntese sucinta e magistral em que o Apóstolo articula os aspectos objetivos e subjetivos da consciência ética, bem como sua dimensão racional e evangélica. A referência objetiva é expressa em termos bíblicos de "Lei", enquanto a posição do sujeito ético é personalizada no eu do próprio Paulo, que em si desenha então o modelo concreto da consciência cristã. "Eu não sou um sem lei (anomos), nem escravo da lei (ypo nomou), mas no meu íntimo sou identificado com a Lei de Cristo" (ennomos Christou) (cf. 1 Cor 9, 21).

Conforme seu estilo costumeiro, Paulo joga com os prefixos especialmente para bem definir nossas relações com Cristo. Aqui, a intimidade, a identificação com o princípio e a regra de vida e de agir exclui o aspecto exterior da norma ética, a heteronomia e a sua imposição, como norma forçada. Fica implicitamente afirmada a autonomia, como o elemento subjetivo da normatividade interiorizada, que é o próprio Cristo. É a expressão ética da mensagem da salvação e santificação evangélicas. Cristo é a vida dos fiéis, na Nova e perfeita Aliança prometida pelos profetas, em que a lei de Deus é inscrita no íntimo do coração (cf. Jr 31, 31; Ez 36, 26-28). É o que encontraremos no tema joanino do Mestre divino e da docilidade ao seu Espírito, e à sua Palavra criadora, em uma identidade com a verdade que é o dom e exigência de total autenticidade.

\section{Obediência, mais o "sentir com a Igreja"}

É nesta visão plena e integral da docilidade à Palavra, que se compreende o sentido da obediência que conforma os cristãos ao plano do Amor universal na medida mesmo em que reconhecem na Igreja o Sacramento desse Amor e se veem conduzidos por ela não à estreiteza de interesses e dispu- 
tas confessionais, mas à amplidão e à profundidade do Amor. Este é o pico da montanha que refulge e atrai no aggiornamento de João XXIII e que o Vaticano II propõe à Igreja e ao mundo do terceiro milênio.

O Concílio é a graça oferecida à Igreja de se libertar para ser libertadora. Ela se reconhece chamada a se libertar, - convém insistir, - não de adversários externos, mas do próprio ciúme ou egocentrismo religioso, de toda pretensão de se impor pela polêmica, pela controvérsia e, o que seria pior, pela força física ou por pressão moral e social.

O Vaticano II não acrescenta apenas uma unidade ao Vaticano I. É um imenso salto qualitativo na história da Igreja. Ela é instada a se converter no que ela é: Povo de Deus, tanto mais de Deus quanto mais é tocado pelo Amor a todo o povo, a toda a humanidade que aí está. A primeira frase de Gaudium et Spes surpreende, levantando a bandeira desta Igreja do Amor: No coração do cristão, há uma fé que não encaixa a vida na estreiteza confessional. Mas, pela fé, esperança e caridade, a Igreja cresce e se excede em um interesse pelas alegrias e esperanças, pelas tristezas e angústias da humanidade toda. E se abre às perspectivas do convívio e da parceria entre confissões religiosas bem como de uma exposição irênica, integral e adaptada da mensagem evangélica. Prioriza as respostas positivas aos desafios da humanidade de hoje. E levanta a bandeira do diálogo universal, ecumênico, inter-religioso e intercultural.

Antes de abordar esse paradigma eclesiológico ideal, hoje em busca de maior viabilidade, é instrutivo olhar para seus primórdios, na aurora da modernidade. Então, emerge o programa urgente de obediência à Igreja, caracterizando a resposta da cristandade ao movimento geral da emancipação. Um bom caminho pode ser retomar e atualizar a dupla atitude conexa, proposta com força e fineza, por Santo Inácio de Loyola: a obediência à Igreja na disponibilidade total às suas ordens, e o "sentir com a Igreja", em uma afinidade de inteligência e coração com o "Mistério da Igreja". É o que dispõe os cristãos "à autenticidade da consciência", que contempla na Igreja o projeto divino de salvar a humanidade e de levar à plenitude a perfeição de sua criatura.

No contexto um tanto asfixiante da emergência, ou melhor, da explosão da Reforma, difunde-se entre os católicos um sentimento de inferioridade diante da certeza jubilosa e exclusiva: só a Deus toda glória, a salvação só pela fé, a verdade toda e só na Palavra divina, nada de devoções, nada de tradições, nada de poder hierárquico. Concentra-se e se torna revolucionário o velho ressentimento contra a Igreja institucional, situação desmobilizadora que remonta à Idade Média.

Tal é contexto que dá relevo e sentido à força mística e militante da eclesiologia dos Exercícios Espirituais de Santo Inácio. São publicados sem 
o nome do santo autor, um pouco como o Manual da Verdade espezinhada, que a Igreja lançava para inspirar e ativar a Reforma Católica. Na perspectiva de uma busca de compreensão da marcha histórica e cultural das atitudes e dos valores éticos, parece bem destacar aqui a exigência da obediência incondicional, bem como o empenho de estabelecer ou restabelecer um sentimento de confiança e de estima envolvendo a totalidade da figura, das atividades e das relações próprias da Igreja ou por ela aprovadas ou abençoadas.

É uma questão de estratégia pedagógica. As "Regras," visando criar ou reforçar o "sentir com a Igreja", se fundam na visão evangélica da Igreja, contemplada especialmente como Esposa bem amada de Cristo e Santa Mãe de seus fiéis. Esta é a alma da verdadeira militância. A urgência da luta leva a acentuar o valor e a necessidade da obediência pronta e total. Mas, no centro dessa mobilização da Igreja que se há de erguer e avançar como eficazmente militante, está bem aceso o ideal de identificação com a Igreja, vista para além da instituição como o mistério de Cristo, oferecendo e exigindo o dom total de seus soldados. Pois, de nada vale o combate no plano das forças políticas, diplomáticas e até mesmo militares. Para Inácio, o combate é espiritual. A estratégia inaciana se enraíza e encontra sua energia na mística evangélica, na união imediata, direta e total com Deus Amor.

Mas, essa mística é deveras realista. O "sentir com a Igreja" se estende a toda a vida da Igreja de então. As devoções, as práticas piedosas, as venerações dos santos e das relíquias, as peregrinações e visitas de santuários, sem esquecer as indulgências, como também os debates entre teólogos, as discussões sobre a graça, sobre a predestinação. Que haja discernimento em tudo. Que os fiéis estejam atentos ao que a Igreja hierárquica aprova. Apeguem-se ao que ela ensina. E não se deixem levar por dúvidas ou mesmo por curiosidades que podem parasitar a vida cristã e, sobretudo, comprometer a comunhão de estima, de deferência e de total confiança na Santa Mãe Igreja. O texto se Santo Inácio (as dezoito "Regras para sentir com a Igreja", anexas aos Exercícios Espirituais) é precioso pela imagem que transmite do catolicismo de seu tempo. Mas, seu verdadeiro valor está na atitude positiva, construtiva, edificante, no sentido forte e preciso, que ele quer despertar e de fato logrou infundir em toda a Igreja desde seu tempo até nossos dias. $\mathrm{O}$ ecumenismo só terá eficácia se começar dentro da própria Igreja.

A realidade ambivalente da história mostra, desde a Renascença e a Reforma protestante, essa dupla dimensão da Igreja. Ela se empenha em mobilizar os fiéis na luta política e por vezes militar contra seus inimigos que a envolvem e atacam com esse estilo ferozmente agressivo visando a derrocada da Instituição eclesiástica. Mas a Igreja leva em frente a sua verdadeira militância, vendo-se, contemplando-se e se promovendo como Corpo Místico de Cristo, portadora da salvação na força do Espírito de santidade e de amor. Na sua redação, bem rente com a realidade, a insistência no «sentir com a Igreja» tem uma acepção menos nobre, mas de eficácia imedia- 
ta. Nada de conflitos na Igreja. Que se aceite tudo o que a Igreja hierárquica aprova ou simplesmente deixa se realizar nas devoções ou práticas dos fiéis. Mas na medida mesma do triunfo dessa renovação, nas elites espirituais que passam pela pedagogia e pela graça renovadora dos Exercícios, o "sentir com a Igreja" se afirma e cresce em seu significado profundo. Na Igreja hierárquica (o termo se difunde então, sob o prestígio de Inácio), na Igreja institucional, apesar dos pesares, resplandece o mistério da Igreja, rosto visível, histórico, comunitário do Mistério da Comunhão Trinitária.

Hoje o ideal da obediência se coloca no clima do diálogo, dentro da Igreja e em seus contatos com o exterior. Uma primeira evidência testemunha o triunfo ao menos da necessidade do "sentir com a Igreja", lembrando as vicissitudes pouco felizes de um passado recente: não estamos tão longe dos santos Pontífices, que tudo apostavam em condenações devassas e excomunhões. Mas, desponta e cresce a certeza salvadora. Sem a confiança, sem instâncias estabelecidas e sem a prática habitual do diálogo, haverá crises de obediência, com a responsabilidade, com a corresponsabilidade partilhada entre Pastores e suas ovelhas.

\section{A Igreja aposta hoje e convida a humanidade a apostar no Amor Universal}

Tal aparece o sentido real e profundo da opção fundadora do Concílio Vaticano II, do qual se comemora o jubileu, na esperança de que a distância dessas cinco dezenas de anos favoreça uma melhor apreciação do que foi projetado, do que foi realizado no Concílio e aplicado ou não depois dele.

Uma primeira grande ideia se destaca a uma observação de conjunto. No seu aggiornamento, a Igreja quer levar a cabo um longo processo histórico em busca de um modelo concreto de sociedade, de forma adequada de organização e de poder, para se fazer presente e ser aceita como comunhão evangélica, aberta ao sentido da história e atenta a uma humanidade em busca dos valores de liberdade e mesmo de emancipação. Despojada dos Estados Pontifícios, a Igreja se via finalmente livre do poder temporal, de uma política exercida sob forma de poder absoluto e sacralizado, em um regime que não a tornava mais sensível às necessidades e aos direitos dos cidadãos. Era antes inclinada ao rigor de um direito penal ambíguo, relevando um poder político e religioso. O Vaticano II pode retomar a tarefa do Vaticano I, em clima favorável de liberdade e de claro discernimento da natureza da Igreja e do poder que de Cristo recebeu para trabalhar pela salvação da humanidade e ajudá-la a compreender e promover os valores e direitos humanos.

A Constituição conciliar sobre a Igreja Lumen gentium prolonga a obra doutrinal do Vaticano I. Mas, para lhe ser fiel no contexto interno e externo da Igreja, reconhece que deve dar mesmo um grande salto qualitativo. Não mais irá partir da Igreja enquanto hierárquica, mas sim da realidade total e profunda da Igreja. Para prosseguir a eclesiologia do Concílio preceden- 
te, aborda o tema do Episcopado, no capítulo III, após ter redefinido a Igreja como "Mistério", presença e manifestação da Santíssima Trindade, Sacramento da reconciliação de Deus e de toda a humanidade (Capítulo I), realizando-se como "Povo de Deus", participante do sacerdócio, do profetismo e da realeza de Cristo (capítulo II). Só então o Concílio passa a expor a doutrina da Igreja hierárquica, no ponto em que a deixara o Vaticano I, o Episcopado. Mas, já no Prólogo se vê bem marcada a originalidade do novo paradigma eclesiológico em continuidade com a doutrina de base, dos dois primeiros capítulos, se proclama que os ministros revestidos do "poder sagrado" estão a serviço do Povo de Deus (n. 18 da Lumen gentium). Uma primeira exposição da colegialidade (que será completada no Decreto Sobre o Múnus dos Bispos) mostra a modalidade de comunhão que o poder hierárquico deve assumir dentro do paradigma tradicional, mas radicalmente inovado pela eclesiologia da Comunhão.

A Igreja definida como "Mistério" e como "Sacramento universal" acentua uma renovação do paradigma teológico que havia mais de um século vinha se afinando nos grandes mestres e nos maiores centros da teologia e cujos continuadores estavam a serviço dos Padres conciliares. Entre eles que se destaquem apenas as figuras de Henri de Lubac e de Yves Congar. Este lembra muito particularmente a Escola de Tübingen, simbolizada por A. M.-J. Scheeben, bem como os começos de uma eclesiologia que faz da Igreja o "Mistério" de acesso aos "Mistérios fundadores" do cristianismo.

Mas, a partir da Constituição sobre a Igreja, e já prenunciada na primeira Constituição, sobre a Liturgia, pode-se constatar a presença de um paradigma fundador e unificador, muitas vezes formulado, mas sempre influindo nas opções e orientações renovadoras e mais ainda inovadoras do Concílio.

Quando se pergunta por que e donde vêm as qualidades primordiais, as propriedades da Igreja, em sua vida interna e em suas relações com as outras confissões religiosas, com a humanidade, com o mundo de hoje, com seus valores e seus problemas, - a resposta adequada vem a ser: a fonte da originalidade singular do Vaticano II é que ele optou pelo paradigma teologal, que prioriza a contemplação de Deus resplandecendo, se dando e se comunicando como Amor Universal. A verificação mais simples dessa opção conciliar de base é a leitura crítica e atenta dos grandes dados e aos matizes dos textos mais marcadamente doutrinais que são os Prólogos e os primeiros Capítulos de todos os Documentos conciliares, sobretudo das quatro Constituições. Nesses textos liminares se antecipa uma elucidação que será completada e aprimorada no conjunto da mensagem exposta em todo o conteúdo de cada texto.

Sem dúvida, como todos os Concílios, o Vaticano I parte do Mistério de Deus, contemplado e admirado na transcendência de seu Ser e de seus Atributos. A singularidade do paradigma de base do Vaticano II está na prioridade efetiva reconhecida ao Amor, ao Amor gratuito, ao puro Amor, 
ao Amor criador, salvador. Providência doadora de todos os bens sem querer (felizmente) se deter em definir dogmas e propor uma ortodoxia, o Vaticano II dá a resposta profunda e adequada ao ateísmo agressivo, insolente ou dissimulado, ao ceticismo generalizado já então e hoje universalizado, rompendo com a antinomia descabida, com a rivalidade entre o Infinito de Deus e o finito de sua criatura. A audácia racional e evangélica do Concílio o impele a tudo ver em referência de dependência e de tendência a Deus. Todas as coisas, as pessoas, os eventos, a história vivida e a histórica narrada, a sociedade com seus valores, o mundo em evolução, tudo que existe, como universo de seres limitados participa da Fonte primeira, do Amor Universal que está no princípio, no fim e no centro da sua criação.

Que se vejam os exemplos mais simples e mais evidentes dessa nova visão teologal da criação, do universo e da história. Uma das características mais visíveis da eclesiologia conciliar, a necessidade radical de busca da unidade evangélica, surge entre os "Irmãos Separados", no Protestantismo, merecendo ser acatado, estimado e promovido como uma inspiração e um dom do Espírito Santo. É o ensino primeiro na primeira parte doutrinal do Decreto sobre o Ecumenismo (n. 4). A salvação da humanidade tem sua fonte nessa presença do Amor Eterno e santificador no seio da humanidade, comunicando universalmente dons e graças, em uma universalidade diferenciada. De modo que a docilidade ao Espírito Santo está em reconhecer a plenitude de sua presença e ação santificadora na Igreja de Cristo, "que subsiste na Igreja Católica". Mas a perfeição desse dom do Espírito não leva a Igreja a se isolar e exaltar em um egocentrismo corporativo, mas a entender a generosidade divina do Espírito de Amor, e assim homologar e agradecer todos os seus dons em todas as comunidades cristãs, nas pessoas e nas instituições, na medida em que recebem e seguem o influxo santificador, que lhe vem de Cristo por seu Espírito.

A mesma compreensão desse influxo de Deus Amor é reconhecido pelo Vaticano II em ação nas outras religiões não cristãs. A missão da Igreja é ir ao encontro do Espírito Santo que precede sua presença missionária junto a esses povos. A missão começa por reconhecer o que há de positivo, de valores humanos universais, que na medida em que são vividos em sua realização desinteressada e gratuita testemunham o efeito da graça que encaminha à salvação. Tais são as linhas de forças da Declaração sobre as relações da Igreja com as Religiões não cristãs e sobre sua Atividade missionária entre os povos a evangelizar.

\section{Para além das noções parciais, a visão integral da Consciência}

Sem se ater à noção vaga e quase inócua da Consciência como capacidade de distinguir o bem e o mal, mais ainda superando a função estreita da Consciência, dentro de uma moral puramente penitencial, na qual é cha- 
mada a apreciar e contabilizar os pecados, o Vaticano II alarga e aprofunda essa realidade central de uma ética dos valores. A consciência "é voz de Deus" abrindo o "coração" ao discernimento das virtudes, à busca da verdade do ser humano como sujeito responsável diante de si, da sociedade e, sobretudo, diante de Deus. A Consciência é, portanto, definida de maneira universal, estendendo-se a todos os aspectos da vida pessoal, comunitária e social, levando em conta os atos, seus efeitos bons ou maus, a permanência das ações e das omissões, que tendem a se estabilizar em hábitos permanentes. Pois, o Concílio reconhece uma historicidade imanente de cada ser humano, das sociedades humanas, de modo que a retidão moral ou a corrupção do pecado tem uma persistência inscrita na história, enquanto tecido de liberdade e de responsabilidade.

Em algumas linhas, Gaudium et spes (n.16) traça e articula todos esses aspectos da consciência, como núcleo de uma ética integral, plenamente humana e suscetível de se abrir à inspiração e à graça do Evangelho; o Vaticano II não cede a um otimismo ingênuo. Ele fala da "dignidade da consciência", como capacidade de discernir e escolher o teor e a qualidade de seu comportamento. A atividade da consciência empenha uma responsabilidade quanto ao presente e ao futuro. Pois, a consciência não se afirma qual série descosida de atos, tem a continuidade de uma faculdade e se aperfeiçoa ou se deteriora, tornando-se mais lúcida e disposta para praticar o bem ou mais hesitante e mesmo menos clarividente e até cega para a percepção do bem a escolher e a praticar.

Convém destacar os dotes da consciência descritos nesse n. 16 de Gaudium et spes, pois eles permitem apreciar o processo histórico tecido de recusa ou de integração de atitudes vividas ou elaboradas para definir este centro da ética humana e mais ainda cristã. O Vaticano II aborda e expõe o tema da consciência na perspectiva do amor, ele retoma a equivalência da consciência e do coração na linha da mensagem bíblica.

Assim, se inaugura o paradigma ético que o Concílio propõe à Igreja e ao mundo, não sob o registro da obrigação, mas, de amor ao bem, a Deus, ao próximo. Longe de qualquer "individualismo ético" (expressão explicada no n. 30 da GS), é o amor universal que estende, desde o coração, o projeto da solidariedade universal de um mundo de retidão moral para as pessoas e as instituições: "Pela fidelidade à voz da consciência, os cristãos estão unidos aos demais homens, no dever de buscar a verdade e de nela resolver tantos problemas morais que surgem na vida individual e social. Quanto mais, portanto, prevalecer a reta consciência, tanto mais as pessoas e os grupos estarão longe da arbitrariedade cega e procurarão conformar-se com as normas objetivas da moralidade." Na frase anterior, se evocava o modelo de relação da criatura e do Criador: Ela se eleva conformando-se à vontade divina: "O homem tem no coração uma lei escrita pelo próprio Deus; a sua dignidade está em obedecer-lhe." 
No fim dessa condensada mensagem sobre a consciência, se indicam as vicissitudes de seu desenvolvimento, com os riscos de sua decadência nos indivíduos e na sociedade:

“Acontece não raro que a consciência erra por ignorância invencível. Sem, no entanto, perder sua dignidade. Isto, porém, não se pode dizer quando o homem não se preocupa suficientemente com a busca da verdade e do bem. E a consciência, pouco a pouco, pelo hábito do pecado se torna quase obcecada".

Essas doutrinas clássicas, desde o advento de uma moral legalista, dita "moral da consciência", se prestavam a um jogo casuístico para se determinar se houve ou não pecado a confessar no tribunal do sacramento da Penitência. O que é significativo e relevante aqui é a utilização geral que faz o Vaticano II de uma doutrina ampla e cuidadosamente elaborada. O Concílio a aplica aos grandes temas do ecumenismo, das relações da Igreja com as outras religiões e de modo geral na apreciação das condições e qualidades morais dos diferentes setores e do conjunto da sociedade. Assim, ele estabelece um clima de confiança e de estima mútua entre as pessoas e as comunidades de "irmãos hoje separados", sejam quais forem as reponsabilidades dos seus antepassados nos apaixonados momentos das separações e das controvérsias. As gerações das diferentes comunidades têm consciência de pertencerem à Igreja de Cristo e assim devem ser acolhidas fraternalmente no diálogo e nos encontros visando a perfeita unidade ecumênica. É o que se expõe, por exemplo, no Decreto sobre o Ecumenismo, cap. I, n. 3.

\section{Ilustração histórica: $O$ avesso da autenticidade da consciência nos equívocos da cristandade}

Pelo paradigma e pela atitude que assumiu, o Vaticano II enfrentou um desafio imenso datando dos velhos tempos e consolidado por exemplos os mais veneráveis. Tudo se pode resumir nessa máxima terrível e danosa: Deus está do lado dos fiéis, sempre em favor deles e para detrimento e infelicidade dos infiéis. A prática dessa triste sentença se torna mundial na aurora da modernidade, com as proezas, em si, maravilhosas, das primeiras travessias oceânicas e especialmente com os Descobrimentos.

Estes levaram a um processo de colonização, quando deveriam viabilizar o encontro fraterno dos povos. Não seria este o plano de Deus que o cristianismo deveria então revelar? Pois bem, os Papas da segunda metade do século XV e começos do século XVI em geral pensam interpretar os desígnios divinos em um sentido totalmente outro. Em virtude de seu supremo poder divino, autorizaram reis cristãos a invadir, subjugar, e colonizar terras e povos infiéis, contanto que essa sujeição dos infiéis estivesse a serviço da evangelização deles. Escravizados seriam mais dóceis para receber o Evangelho e o batismo. 
Ainda bem que havia missionários que tinham outra compreensão, a boa compreensão do Evangelho. Alguns deles informaram o Papa Paulo III, que condenou essa práticas como desumanas e antievangélicas. E proclamou o direito natural desses povos a serem reconhecidos como homens, como criaturas de Deus, às quais o Evangelho deveria ser anunciado com afabilidade e todo respeito à liberdade deles. Isso em 29.05.1537, com a bula Sublimis Deus, visando especialmente os Reis Católicos da Espanha que tinham recebido plenos poderes das mãos de Alexandre VI para colonizar a América. Aliás, esses Reis Católicos, Fernando e Isabel, juntam às suas assinaturas o qualificativo de "Domadores dos povos". A atitude plurissecular da cristandade em relação à escravidão, as posições intransigentes dos papas dos séculos XVIII e XIX, culminando no Sílabo de Pio IX, tudo isso são exemplos do apelo ao Deus todo poderoso, para que esteja do lado de seus fiéis, não para os mudar em suas vidas e suas ideias, mas para protegê-los em seus desmandos e injustiças.

\section{A conversão total da Igreja ao Deus Amor universal, para que seja uma comunidade semelhante a Ele, tal é o projeto do Vaticano II, a partir de seu paradigma teologal}

Daí, se pode resumir as grandes linhas do Concílio: um paradigma teológico global inspira paradigmas particulares: antropológicos, cristológicos, eclesiológicos e éticos.

Semelhante paradigma só se torna viável, na medida em que esse desígnio de universalidade de um amor transformador se concretiza em um projeto de abater as barreiras e de lançar pontes, para que o povo de Deus se disponha a ir ao encontro daqueles que foram tratados até ontem como adversários e devem agora ser aceitos e acatados como parceiros na busca da Verdade.

Como dar corpo ao ideal de aggiornamento inspirado por João XXIII? É a preocupação primordial que anima o Concílio. Apos ter alcançado a sua autonomia, ele começa por rejeitar os projetos de resposta à proposta do Papa, dados no feitio do Sílabo por uma parte da Comissão preparatória. Ele toma então uma posição criativa. Propõe uma série bem ordenada de formas de renovação, na convicção de que essas velhas falhas ou distorções persistentes afastavam a Igreja do modelo evangélico de comunidade, distanciando-a também das aspirações e necessidades do mundo moderno.

Visa, portanto, tornar a Igreja mais evangélica e mais moderna. Ela há de estar mais próxima senão dentro do mistério de Deus que se dá à humanidade, sendo a Igreja comunhão de graça e santidade, conformando-se assim ao Evangelho. Mas essa generosidade, esse amor gratuito faz com que, em seu íntimo, a Igreja esteja vizinha e mesmo presente ao mundo, mais disposta a olhar objetivamente para o mundo, na certeza de que, no intercâmbio com o mundo de hoje, ela pode ensinar e aprender (GS n. 40). 
Os Padres conciliares são guiados primeiramente por um sentido de Deus que se manifesta pelas vias do amor e da bondade, não impondo leis, nem mesmo se impondo a si mesmo, mas se dando para ser aceito livremente. Tal é a mensagem primordial da Constituição Dei Verbum, sobre a Revelação (18 de novembro de 1965). Em todos os Documentos em que se aborda a natureza da Igreja, seus elementos constitutivos e suas qualidades primordiais, vem bem traçada essa semelhança e união com Deus que dá e exige laços de amor. Se todas as criaturas e todos os fiéis estão ligados na dependência ao Criador e Salvador, então se devem reconhecer entrelaçados entre si. É esse entrelaçamento, essa coerência inscrita no universo das coisas e das pessoas que caracteriza a visão global do Concílio. Ele segue e propõe o paradigma teologal de Deus Amor universal, do qual decorre um feixe de paradigmas de uma total solidariedade, sem excluir qualquer criatura de Deus, intimamente a Ele ligada no íntimo de seu ser de criatura e chamada à santidade sob a ação escondida da graça ${ }^{4}$.

Assim, a inspiração primeira de todos os Documentos conciliares no que têm de primordial, enquanto se integram no grande projeto renovador do Vaticano II, vem a ser o paradigma teologal. Nele se reconhece e proclama que o mesmo e único Deus é criador e santificador, Senhor do tempo e da eternidade, que Ele assume e valoriza a criação na salvação, sendo o Senhor da história e da escatologia. Pois, pelo Evento de Páscoa e de Pentecostes, pela missão do Filho e do Espírito, o Pai inaugura a presença transformadora da escatologia dentro da história, promovendo como virtudes evangélicas e como valores humanos a justiça, a liberdade, a verdade e a solidariedade transformando os corações e as sociedades. O mundo, a secularidade, as realidades terrestres são vistas e estimadas em sua consistência, em sua autonomia, mas por esta sua mesma natureza própria já estão colocadas em relação com o Amor universal, o Deus Criador, Providência, Salvador e Santificador. Por isso, a autenticidade no mundo profano, no cuidar das coisas e no dar-se ao serviço dos seres humanos constitui a retidão da ética humana, ao mesmo tempo exigida e favorecida pela vocação evangélica.

Esta visão de Deus na transcendência e na condescendência de seu amor é o ponto de referência sempre acima e à frente das atividades conciliares dando uma coerência singular às doutrinas elaboradas e promulgadas, pois elas visam à realidade do mistério que é a Igreja, comunhão de graça e santidade, apontando também para a realidade do mundo humano, em sua complexidade, em continuidade com a Igreja, pois ele é trabalhado, em formas e medidas diferentes, pelo mesmo Espírito, que anima a Igreja e a inclina a estar em intercâmbio com o mundo.

\footnotetext{
${ }^{4}$ Essa tese sobre o paradigma fundador do Concílio, da qual se antecipam aqui uma condensação, constitui o tema de um livro que edito neste momento: Vaticano II, A Igreja aposta no Amor Universal.
} 


\section{Paradigma teológico de Cristo e do Espírito}

O paradigma teológico fundador e inspirador do Concílio, fonte primeira de sua singularidade, é, portanto, um paradigma trinitário, explicitando-se em um paradigma cristológico e pneumatológico.

Como eixo de leitura da I Parte da Gaudium et Spes, é importante atender sempre àquela trilogia tão significativa: a antropologia rica de virtualidades, de promessas e riscos, perfectível e defectível, a escatologia pessoal, comunitária e social, histórica e transcendente; e, em conexão com essa antropologia e essa escatologia, a cristologia, o Verbo Encarnado que está no princípio, no dinamismo e no termo do mundo humano e terrestre, em processo evolutivo, na visão dos cientistas, o que o Concílio está longe de contestar, mas que ele mesmo contempla à luz e na perspectiva do plano da ação de Deus pelo seu Filho feito homem.

A Constituição Gaudium et Spes considera a humanidade na dignidade da pessoa e também, na atividade, na ação apreciada como a energia aprimoradora do próprio ser humano, seu protagonista, e como transformadora do universo; vê e analisa ainda a comunidade cada vez mais aglutinada pelo progresso tecnológico. Esse tríplice elemento, a dignidade da pessoa, a atividade humana no mundo, a solidariedade crescente na humanidade, essa antropologia complexa e dinâmica é então apreciada na linha da escatologia individual e coletiva como sendo o campo imenso e constante da ação elevadora e transformadora do Verbo Encarnado, do Cristo Homem-Deus, conduzindo o homem para Deus.

É neste imenso quadro de uma antropologia teológica que resplandece a afirmação conciliar que evoca e prolonga os primeiros Concílios cristológicos: "Por sua Encarnação, o Filho de Deus se uniu, de certo modo, a cada ser humano" (GS n. 22).

A universalidade do Amor de Deus Criador, que fez as criaturas racionais para serem parceiras de sua amizade na história e para além da história, refulge como o Mistério que não visa desafiar a inteligência, mas, tocar o coração da humanidade. O Concílio está bem no centro de sua opção original e fundadora: o dom total da Encarnação, de Deus se dando à humanidade e a cada ser humano é a fonte de toda sabedoria e de todo sentido para cada existência e para toda a história.

Mais ainda, esse Dom divino total, visando suscitar a doação gratuita e total assume e transforma a Igreja. Faz dela a Comunidade animada pelo Amor universal, que pelo seu próprio ser ela é destinada a anunciar e testemunhar, constituindo-se em "Sacramento da reconciliação do Universo", - o que era a primeira definição da Igreja na Constituição Lumen gentium (n. 1). Na Constituição Dei Verbum, sobre a Revelação, o Concílio proclama: "Em sua doutrina, vida e culto, a Igreja perpetua e transmite a todas as gerações tudo o que ela é, tudo o que crê" (DV n. 8). 
Em correlação com esse paradigma trinitário, o Vaticano II insiste sobre a missão do Espírito universalizando a Igreja por dentro, dando-lhe uma consciência mundial. Nos pontos decisivos dos Documentos que caracterizam a originalidade da Igreja, o Concílio aponta para o desígnio do Pai inaugurado pelo Filho na história da salvação e realizado plenamente pelo Dom do Espírito no íntimo de cada um e na comunidade de consciências que constitui a Igreja. O Povo de Deus é uma comunhão no Espírito e do Espírito. A Igreja é comunidade tecida de comunidades. O Concílio não hesita em proclamar, falando das igrejas particulares: "é nelas e a partir delas que existe a Igreja Católica una e única" (LG n. 23).

Assim, a colegialidade e a participação, práticas internas e externas do diálogo, bem como a tendência à união ecumênica, são propriedades da Igreja que vêm marcadas por certo condicionamento histórico. Mas, em sua essência, em sua verdade profunda, elas decorrem do Dom e da ação íntima do Espírito. O Concílio o lembra para acentuar bem que as noções propostas nas suas posições mais decisivas e incisivas são apelos a que a Igreja seja de maneira mais plena o que ela é como comunidade do Espírito de amor e unidade. Os fiéis e as comunidades são animados pelo Espírito Santo, que assiste os Pastores e multiplica dons e carismas a serviço da Comunidade. Havemos de ser atentos à assistência do Espírito ao Magistério, porém muito mais ainda à habitação do Espírito Santo, que ilumina, guia e santifica os fiéis. Tal é a mensagem especialmente explicitada nas Constituições sobre a Igreja e sobre a Revelação.

Na Constituição sobre a Igreja e o Mundo se destaca a mensagem do Espírito em sua atividade fora da Igreja institucional. Dessa forma, o Vaticano II se caracteriza por sua nova visão da atividade eclesial ad extra, das relações da Igreja com as religiões e com o mundo. Reconhece e exalta a ação do Espírito no conjunto das comunidades cristãs, nas diferentes religiões, na procura e prática dos valores espirituais, que marcam as civilizações e as culturas. Veja-se, por exemplo, GS n. 11, 16, 37, 41. A presença e a ação do Espírito aí se manifestam na história, no mundo, na sociedade, no progresso humano verdadeiro. Reconhecendo e acatando esses valores a Igreja se mostra dócil ao Espírito Santo que a anima.

Há, portanto, uma pneumatologia subjacente na doutrina sobre a presença e atividade do Espírito na Igreja, na história, difundindo dons diferenciados, mas correlativos, nas religiões, na marcha cultural da humanidade, no progresso dos valores humanos. É esta visão do Espírito que funda a existência e a exigência do diálogo ecumênico, inter-religioso e intercultural. (UR n. 1; 2, 4,7; PO n. 22; GS n. 22, 5; 26). Esse paradigma de Deus Amor universal, se dando e revelando na Comunhão Trinitária, refulge com muita força e beleza já nos limiares, nos Prólogos das Constituições e Documentos mais inovadores do Vaticano II, nos Decretos Sobre o Ecumenismo, sobre a Atividade Missionária da Igreja, na Declaração sobre a Relação da 
Igreja com as Religiões não Cristãs, e, de maneira bem construída, na Declaração sobre a Liberdade Religiosa.

\section{Comunhão trinitária, comunhão dos santos e plena solidariedade humana}

O Deus Amor que está presente e inspirando e guiando as atitudes e posições doutrinais do Concílio é o Deus do Evangelho, Pai, Filho e Espírito Santo. De início, pode ser surpreendente esse apelo constante ao Mistério que nos excede de toda a parte. Com semelhante apelo, o Concilio busca impelir-nos a promover a ação renovadora da Igreja e da sociedade. A questão é pertinente e fecunda. Ela nos leva a permanecer atentos à originalidade singular do Vaticano II. Ele qualifica e eleva a ação dos cristãos, fazendo-os estar em contato com o que há de melhor e mais excelente.

A força em que aposta o Vaticano II e leva a Igreja a apostar é primeiramente Deus, contemplado em si mesmo, qual Comunhão de vida, de verdade e de amor, modelo e fonte de todo projeto de plena realização de sua bem-amada criatura racional e livre. Em seu conteúdo essencial e em seu dinamismo divino, toda a vida cristã se condensa na fé que nos identifica com a Comunhão de Amor, a Unidade / Trindade: Pai, Filho, Espírito Santo. E faz surgir, constitui e anima a Comunhão dos santos, dos que são consagrados e divinizados "em nome" e para "a glória do Pai, do Filho e do Espírito Santo". E essa comunhão de graça, segundo a grande insistência da escatologia do Vaticano II, é o verdadeiro objeto de esperança, se e na medida em que ela vê o triunfo da Glória e do Amor antecipado na solidariedade encarnada em todas as atividades, relações e formas de sociedade humana.

Essa visão integral e bem ordenada de todas as realidades e verdades da fé e da vida cristã está muito especialmente inserida e expressa na Constituição Lumen gentium sobre a Igreja. Para ser a base de todo o projeto renovador que visa ser o Concílio, a Igreja resplandece nessa Constituição, qual Comunidade da Santíssima Trindade, sacramento da reconciliação universal, privilegiando o povo de Deus, valorizado no laicato, realizandose na terra e no céu, tendo sua plena realização em Maria.

Sintetizando a fé na Comunhão Trinitária e na Comunhão dos Santos, o Concílio nos conduz a uma espiritualidade integral e hierarquizada, com toda a justeza, em torno do eixo: primado absoluto do sentido de Deus, inspirando uma devoção bem ordenada a Maria e aos santos. Essa esperança teologal nos encaminha a uma atitude prática do dom de nós mesmos na consagração à glória, ao reino de Deus no céu (santificação, evangelização) e sua antecipação prefigurada na terra (promoção da fraternidade e da solidariedade social).

Tal é o sentido profundo de nossa profissão de fé, pela qual temos a felicidade e a responsabilidade de "crer no Amor universal". Esse amor nos 
une na caridade, amor divino, dom de nós mesmos em busca da vida eterna para todos e da promoção de uma sociedade verdadeiramente humana, onde todos possam encontrar as condições para viver, para conviver na solidariedade, no respeito e na prática de todos os direitos para todos.

Assim, a vida cristã é proposta pelo Concílio como projeto ético culminando na mística, pois essa vida pessoal e comunitária decorre da Comunhão trinitária e nos leva à comunhão dos santos e à solidariedade plena e verdadeiramente humana. Não pode haver ruptura. O Evangelho é para nós a acolhida do Reino do Pai, por seu Filho e em seu Espírito e compromisso constante de justiça e de paz sobre a terra.

\section{Paradigma eclesiológico}

Esse paradigma se encontra na base da Constituição LG. Ele inspira a Constituição DV, especialmente o cap. $2^{\circ}$, no que toca à missão da Igreja na transmissão da Revelação. Ele está presente nos documentos que determinam as posições conciliares no plano ecumênico, missiológico, face ao pluralismo das religiões e culturas.

A singularidade do Concílio tem aqui seu ponto alto. Ele se empenha em propor uma alternativa ao modelo dos Concílios eclesiológicos anteriores, que, ao menos em parte, merecem o nome de eclesiocêntricos. Sempre com os olhos fitos no Amor divino universal e totalmente gratuito, o Vaticano II se dá a difícil e sublime missão de definir a "plenitude" da Graça pelo "vazio" da prepotência, definir o pléroma pela kenose, mostrar a plenitude dos dons e da presença do Espírito através do vazio da pretensão e da prepotência humanas. Dessa forma, ele visa definir a Igreja como a Igreja da Cruz e do Espírito, como a perfeita mediação, que se revela deveras eficaz, porque de todo transparente.

Essa teologia propõe e ordena umas tantas prioridades, cujo feixe constitui o paradigma eclesiológico do Concílio Vaticano II. Antes de tudo, a Igreja é vista concretamente como povo de Deus, como realização plena e perfeita das qualidades bíblicas do povo escolhido por Deus e para Deus, amoldado segundo Deus pela pedagogia de Deus. E por que não reconhecer que o Vaticano II está dentro da sensibilidade moderna e fala para a mentalidade moderna que distingue o povo e a massa. Pois, o povo é coletivo nobre, protagonista da civilização, chamado a ser ativo, a participar, a assumir e exigir responsabilidade.

Convém explicitar um dado importante na história e na atualidade do cristianismo. O Vaticano II se caracteriza por sua atitude de valorizar a "habitação", a permanência habitual e ativa do Espírito Santo, animando toda a Igreja, todos e cada um dos fiéis. A comunidade é chamada a ser a realização peregrinante da Comunhão dos Santos, a força evangelizadora de Deus no mundo. Em tempo de crises, de controvérsias e polêmicas, a 
tendência da cristandade era estar de olhos atentos vigiando o povo e valorizando a autoridade religiosa, que seria apoiada e guiada pelo Espírito Santo para perpetuar a autoridade divina recebida de Cristo Fundador da Igreja. Para o Vaticano II, o Povo de Deus é uma comunhão no Espírito e do Espírito. A Igreja é comunidade tecida de comunidades. Nela o Espírito Santo assiste os Pastores para que tudo façam a fim de obter e manter o essencial, a graça do Espírito Santo no coração de todos.

Em síntese, esse paradigma se encontra na base da Constituição LG. Ele inspira a Constituição Dei Verbum, especialmente o cap. $2^{\circ}$, no que toca à missão da Igreja em viver e transmitir a Revelação. Ele está presente nos documentos que determinam as posições conciliares no plano ecumênico, missiológico, face ao pluralismo das religiões e culturas.

Esta é a admirável e escondida presença ativa do Espírito ad intra, no coração da Igreja, o que pede uma docilidade multiforme e coerente de todos os fiéis. O Vaticano II se caracterizou por sua atenção à atividade ad extra, exercida pelo Espírito fora da Igreja institucional, mas no conjunto das comunidades cristãs, nas diferentes religiões, e mesmo no mundo profano à procura e na prática dos valores espirituais, que marcam as civilizações e as culturas.

\section{Paradigma antropológico}

Na Constituição Gaudium et spes, o Vaticano II chegou finalmente a proferir sua definição do ser humano, após um trabalho exemplar, de longo e penoso tatear, para atender a todos os elementos e aspectos dessa compreensão integral, sem resvalar no perigo das abstrações filosóficas.

Em nosso esboço de leitura, ficou assinalado o grande achado do Concílio. Ele soube tirar todo proveito da junção dessa dupla visão cultural e bíblica: a dignidade singular da pessoa em sintonia com a imagem divina, de que ela é revestida, no plano da criação e da salvação.

Assim, no capítulo da economia, fica-se surpreendido pela compreensão humana da empresa que propõe o Concílio, afirmando a conveniência e mesmo a exigência da participação de todos nos lucros e na vida dessa empresa, todos esses dados de ética pessoal e social são fundados e explicados à luz da dignidade singular da pessoa, reconhecida como feita à imagem de Deus (cf. GS n. 68).

\section{Do novo paradigma antropológico ao novo paradigma ético}

Pois, destaca e ordena os elementos essenciais: de natureza e cultura, de presença ao mundo e de capacidade transcendental de Deus, de criatura e de elevação sobrenatural, de condição pecadora e de vocação à santidade e à edificação de um mundo melhor, de identidade pessoal e de relação social, de missão histórica e de destino eterno. 
O Concílio começa por uma opção negativa decisiva. Trata-se da rejeição do projeto pré-conciliar De ordine morali christiano. Nesta proposição de uma "ordem moral cristã" pelo antigo Santo Ofício e na sua rejeição pelo Concílio, temos o mais claro e importante embate de paradigmas éticos dentro da mesma Igreja Católica e no interior de sua ortodoxia.

No Decreto sobre a formação dos Padres, Optatam totius, o Vaticano II apresenta uma espécie de paradigma ideal para o "aperfeiçoamento" da teologia moral. Ele consagra os resultados de um esforço renovador e propõe alguns parâmetros para a obtenção completa desses objetivos. Ele pede "um cuidado especial em aperfeiçoar a teologia moral" pondo em relevo que sua "apresentação científica seja mais nutrida da doutrina da Sagrada Escritura, ponha em plena luz a grandeza da vocação dos fiéis em Cristo e sua obrigação de produzir frutos na caridade para a vida do mundo" (cf. Decr. cit. n. 16).

Longe de expor uma ordem moral a assegurar e a defender, por via autoritária, LG funda e GS desenvolve uma ética humana de inspiração evangélica de caráter positivo, antropológico, cristológico, pneumatológico, sacramental. Propõem o amplo modelo de um novo paradigma ético, assessorado por excelentes teólogos moralistas.

\section{Paradigma de ética fundamental, típico de "Gaudium et Spes"}

Esse paradigma de ética fundamental é plenamente evangélico, precisamente porque realiza a conjunção, a sinergia do humano e do divino. À luz e no prolongamento da Encarnação, tudo o que é humano é afirmado em sua consistência, em seu significado e em seu valor próprios, para se unir e se elevar no encontro de amor e de submissão a Deus, que se dá e se revela na sua intimidade e na sua transcendência.

Quanto ao essencial, o Concílio elabora uma ética dos valores, não das obrigações, dos mandamentos ou deveres. Privilegia o valor da dignidade, que reconhece como o correspondente humano da noção teológica da Imagem de Deus. Assim, após ter aberto a sua exposição pelo enunciado da "Dignidade da pessoa humana" (GS I Parte, cap. $1^{\circ}$ ), o Concílio não teme a redundância, falando com visível complacência da "dignidade da inteligência" (n. 15), da "consciência" (n. 16), da "liberdade" (n. 17), como exaltará a "dignidade do matrimônio e da família" (II Parte, cap. $1^{\circ}$, n. 47s). Mas, sobretudo, essa ideiachave ilumina toda a exposição da doutrina e de suas aplicações.

Assim, na Gaudium et Spes, a ética é olhada e tratada de maneira integral, em sua dupla dimensão pessoal e social. Essa ética fundamental se caracteriza, então, pela primazia que ela dá à conjunção ou à sinergia desse duplo valor: a dignidade e a responsabilidade. Trata-se de uma prioridade absoluta e constante, afirmada e aplicada efetivamente em todos os domí- 
nios de Gaudium et spes. Desses dois princípios, deveras fundadores, derivará toda a constelação dos valores que formam o firmamento ético.

A dignidade humana resplende qual valor social, pois é tida como referência normativa, objetiva e universal. De fato, o respeito à dignidade da pessoa humana se impõe como imperativo absoluto, para que a sociedade se una em um consenso autenticamente humano. Ela será o primeiro princípio de autenticidade e de unidade para o próprio sujeito ético, para todos e cada um dos membros da sociedade, e para essa mesma sociedade, considerada como um todo. Mas essa dignidade humana tem uma dimensão subjetiva igualmente fundamental. A dignidade da pessoa inspira e suscita a responsabilidade.

Sob esse aspecto subjetivo, a novidade mais típica do Concílio é a proposição de uma ética da responsabilidade, que integra e leva à perfeição a moderna aspiração à liberdade e às liberdades. Ela confirma e qualifica essa aspiração à liberdade, tornando-a um valor ético de base, dando-lhe o lugar de uma virtude universal, o equivalente da virtude clássica de prudência pessoal e política. No plano social, a responsabilidade será levada a se desdobrar nas atitudes de participação e de partilha, inspirandose no respeito da dignidade da pessoa e na promoção do bem comum.

A responsabilidade é a realização plena e adulta da liberdade, como apetite racional do bem, para si, para o outro e para a coletividade. Nessa perspectiva, a novidade mais típica do Concílio é a proposição de uma ética da responsabilidade, que integra e leva à perfeição a moderna aspiração à liberdade e às liberdades.

Dessa forma, em vez de condenar o subjetivismo, o Concílio procura estabelecer o justo equilíbrio e a plena conciliação da dimensão objetiva e subjetiva da ética. Ele se inspira na tradição, dando provas de uma fidelidade dinâmica e criativa. Com um mesmo discernimento, acolhe a modernidade em suas aspirações e seus valores mais profundos. É que o Vaticano II permanece atento ao Evangelho que afirma: nada da lei está abolido; mas insiste com o mesmo vigor: o homem não foi feito para o sábado, mas o sábado para o homem (cf. Mt 5, 17; Mc 2, 27).

\section{Em síntese. Originalidade essencial e primordial do Vaticano II}

O paradigma ético de Gaudium et spes mostra uma verdadeira criatividade do Concílio para indicar novos caminhos, mas ele mesmo não abria ainda esses caminhos. Nem os poderia abrir. A originalidade essencial e primordial do Vaticano II é que ele quer inaugurar, na Igreja e pela Igreja no mundo, uma nova idade criativa. Seu primeiro intento é de instituir ou de ao menos sugerir a ética da responsabilidade, da participação e do discernimento, capaz de encontrar e até mesmo de inventar modelos de 
decisão e de ação, na fidelidade ao Evangelho e aceitando os desafios do mundo moderno.

Aceitar e analisar a realidade, especialmente a realidade social, tal é o corolário da atitude conciliar de estima e valorização da criação, de fidelidade à Encarnação, de confiança no triunfo pascal de Cristo, se efetuando e manifestando na história e marchando para o pleno cumprimento da escatologia. Tal é o princípio fundador do paradigma ético da cultura. Gaudium et spes repete, com a maior insistência: "Os valores da dignidade humana, da comunidade fraterna e da liberdade, todos esses bons frutos da natureza e de nosso trabalho, nós os reencontraremos... iluminados e transfigurados... O Reino já está presente em mistério aqui na terra. Chegando o Senhor, ele se consumará" (GS n. 39).

Através dessa formulação de grande simplicidade, afirma-se a conviç̧ão que inspira um empenho pessoal e comunitário: "Procurar as coisas do alto, longe de diminuir, antes aumenta a importância da missão de construir junto com todos os homens um mundo mais humano" (n. 57).

\section{Todos serão teodidatas $(J o$ 6, 45).}

Ainda uma última sugestão evangélica iluminando a visão integral da ética proposta e elucidada pelo Vaticano II.

Em um de seus derradeiros documentos, a Declaração Dignitatis humanae sobre a Liberdade Religiosa, o Vaticano II quis encerrar em beleza o velho conflito que opunha a modernidade ciosa de emancipação e a cristandade apegada a assegurar a ortodoxia mediante a rigorosa obediência à hierarquia. Ao apagar das luzes, no empenho de dar todo fulgor ao seu elã inovador, o Concílio abre esse documento audacioso, dando o maior destaque à aliança indissociável da fé e da liberdade.

Empenha-se em demonstrar sua mensagem com uma cerrada argumentação evangélica. Apoia-se em Cristo que se revela e define como a Verdade no centro do IV Evangelho, o Evangelho da estreita conexão da Verdade e do Amor. A Declaração conciliar se concentra na reiterada proclamação do Filho de Deus: crer ou não crer, aceitar ou não sua Palavra é um "julgamento" que se passa no íntimo do ser humano, sob a ação iluminadora do próprio Pai. A autenticidade da criatura racional está em "ser da Verdade". Ela se realiza plenamente pela Fé, acolhendo a Verdade em um processo de livre e amorosa afinidade com ela.

Tanto no Prólogo quanto na Conclusão, a Declaração Dignitatis humanae se coloca no contexto de uma estima crescente que a humanidade vem mostrando do valor primordial da liberdade. Em seu término, o Concílio retoma seus debates da I Sessão, seu intento de conciliar Verdade e Liberdade, levando à feliz conclusão essa mensagem que amadureceu em um 
processo progressivo. Agora a Declaração sobre a Liberdade se mostra significativa da originalidade do Vaticano II, na harmonia que ele estabelece entre a visão da Igreja como comunhão, como a valorização dos leigos, com a missão própria deles de ser santos e de testemunhar o Evangelho no mundo. O que leva à proposição insistente do diálogo, do ecumenismo e à abertura simpática ao mundo moderno. A bandeira da liberdade avançava enfrentando dificuldades e oposições da parte dos que desejavam conformar-se às posições tidas e ditas tradicionais, quando eram apenas uma adaptação menos rude do Sílabo de Pio IX.

Essa derradeira tomada de posição de todo o Concílio, concretizada na Declaração Sobre a Liberdade, com razão se ostenta como fidelidade ao cerne da pregação evangélica. E então, a afirmação da Liberdade se articula com a atitude da fé, com o processo de acolher a verdade divina e mesmo de se converter a essa verdade, que tem a eficácia de uma graça, de uma luz revelando o Pai pelo Filho no Espírito Santo.

Com os olhos na Escritura e na plena realização das Promessas que o Pai está cumprindo em seu Filho, Jesus proclama: “Nos Profetas está escrito: todos serão Teodidatas" (Jo 6, 45). Todos serão discípulos diretos e imediatos de Deus, dele recebendo e acolhendo a Verdade divina no íntimo do coração por ela transformado. Esta palavra luminosa resume a revelação evangélica em toda sua força e beleza. O ser humano se afirma e é confirmado na autenticidade de sua consciência, na confiança e obediência à Igreja, enquanto mediadora fiel e transparente do Espírito de verdade e de amor, que pede docilidade na autonomia, na liberdade que se faz criativa pelo amor.

Frei Carlos Josaphat, 91 anos, Frade Dominicano. Doutor em Teologia Moral, com especialidade em Ética de Comunicação Social. Lecionou por 27 anos na Universidade de Fribourg, Suíça, da qual é Professor Emérito. Escreveu algumas dezenas de livros, em português, francês, espanhol, italiano. Entre eles vários dizem respeito ao tema deste artigo: Tomás de Aquino e a Nova Era do Espírito. São Paulo: Loyola, 1998. Bartolomeu de Las Casas, todos os direitos para todos. São Paulo: Loyola, 2000. Ética Mundial, esperança da humanidade globalizada. Petrópolis: Vozes, 2010. Paradigma teológico de Tomás de Aquino, São Paulo: Paulus/EDT, 2012.

Endereço: Rua Pedro Batista Martins, 173 - Aarão Reis 31814-340 Belo Horizonte - MG 